\title{
NNMT wt Allele
}

National Cancer Institute

\section{Source}

National Cancer Institute. NNMT wt Allele. NCI Thesaurus. Code C104567.

Human NNMT wild-type allele is located in the vicinity of $11 \mathrm{q} 23.1$ and is approximately 55 $\mathrm{kb}$ in length. This allele, which encodes nicotinamide $\mathrm{N}$-methyltransferase protein, plays a role in the detoxification of metabolism of xenobiotic compounds. 